Volume 3 Issue 1 (2019) Pages 146 - 152

Jurnal Obsesi : Jurnal Pendidikan Anak Usia Dini

DOI: $10.31004 /$ obsesi.v3i1.155

\title{
Memahami Bahasa Anak Usia 14 Bulan melalui Unsur "Non-Linguistik"
}

\author{
Risanti Amelin ${ }^{1 凶}$, Syahrul Ramadan ${ }^{2}$, Erizal Gani ${ }^{3}$ \\ Program Studi Magister Pendidikan Bahasa dan Sastra Indonesia \\ Fakultas Bahasa Seni, Universitas Negeri Padang
}

\begin{abstract}
Language is the most important means of communication in human life, with language, people are more easily conveying messages to other humans. both in written form, verbally, or only in the form of certain symbols. This research was conducted to understand the meaning of the words spoken by 14-month-old children through activities and non-linguistic elements. This study aims to describe the process of understanding children's language through activities and non-linguistic elements. The non-linguistic elements in question are such as gestures, expressions, and objects designated by the child. There are two causes, namely, First, children's language is still limited. Second, what the child says is something that most attracts his attention. The subject of this research was a boy named Riziq Alfath Aguero. Riziq is 14 months old. The researcher observed two video recordings that had been carried out on the child observed. The two videos were carried out at different times. The results of the study showed that with facial expressions and gestures helping people around to understand what the child meant.
\end{abstract}

Keywords: Language; Uunderstanding Languag; Early Childhood; Non-linguistics

\begin{abstract}
Abstrak
Penelitian ini bertujuan untuk mendeskripsikan proses memahami bahasa anak melalui aktivitas dan unsur non-linguistik. Unsur non-linguistik yang dimaksud seperti gerak isyarat, ekspresi, dan benda yang ditunjuk si anak. Ada dua penyebab yakni, Pertama, bahasa anak masih terbatas. Kedua, yang diucapkan sang anak adalah sesuatu yang paling menarik perhatiannya. Subjek penelitian ini adalah seorang anak laki-laki bernama Riziq Alfath Aguero. Riziq berusia 14 bulan. Peneliti melakukan pengamatan terhadap dua rekaman video yang telah dilakukan terhadap anak yang di amati. Dua video tersebut dilakukan pada waktu yang berbeda. Hasil penelitian menunjukkan bahwa dengan ekspresi muka dan gerak tubuh membantu orang sekitar untuk memahami yang dimaksud sang anak.
\end{abstract}

Kata Kunci: Bahasa; Memahami Bahasa Anak; Anak Usia Dini; Non-linguistik

@ Jurnal Obsesi Prodi PG-PAUD FIP UPTT 2017

$\triangle$ Corresponding author:

Address : Dusun Selatan Jorong Pasaman Baru

ISSN 2356-1327 (Media Cetak)

Email : risanti.amelin@yahoo.com

ISSN 2549-8959 (Media Online) 


\section{PENDAHULUAN}

Bahasa merupakan sarana komunikasi terpenting dalam kehidupan manusia, dengan bahasa, manusia lebih mudah menyampaikan pesan kepada manusia lainnya. baik dalam bentuk tulisan, lisan, maupun hanya dalam bentuk symbol tertentu.

Bahasa adalah sebuah sistem yang didasarkan pada kata-kata dan tata bahasa yang memfasilitasi komunikasi, yang merupakan elemen mendasar dalam perkembangan kognitif anak (Urška Fekonja, 2014)

Menurut Arifuddin (Fatmawati, 2015), tahap pemerolehan bahasa dibagi menjadi empat tahap, yaitu praujaran, meraban, tahap satu kata, dan tahap penggabungan kata sebagai berikut:

\section{Tahap Pralinguistik (Masa Meraba)}

Pada tahap ini, bunyi-bunyi bahasa yang dihasilkan anak belumlah bermakna. Bunyi-bunyi itu memang telah menyerupai vokal atau konsonan tertentu. Tetapi, secara keseluruhan bunyi tersebut tidak mengacu pada kata dan makna tertentu. Fase ini berlangsung sejak anak lahir sampai berumur 12 bulan.

Pada umur 0-2 bulan, anak hanya mengeluarkan bunyi-bunyi refleksif untuk menyatakan rasa lapar, sakit, atau ketidaknyamanan. Sekalipun bunyi-bunyi itu tidak bermakna secara bahasa, tetapi bunyi-bunyi itu merupakan bahan untuk tuturan selanjutnya.

Pada umur 2-5 bulan, anak mulai mengeluarkan bunyi-bunyi vokal yang bercampur dengan bunyi-bunyi mirip konsonan. Bunyi ini biasanya muncul sebagai respon terhadap senyum atau ucapan ibunya atau orang lain.

Pada umur 4-7 bulan, anak mulai mengeluarkan bunyi agak utuh dengan durasi yang lebih lama. Bunyi mirip konsonan atau mirip vokalnya lebih bervariasi.

Pada umur 6-12 bulan, anak mulai berceloteh. Celotehannya merupakan pengulangan konsonan dan $\mathrm{v}$ okal yang sama seperti/ba ba ba/, ma ma ma/, da da da/.

\section{Tahap satu - kata}

Fase ini berlangsung ketika anak berusia 12-18 bulan. Pada masa ini, anak menggunakan satu kata yang memiliki arti yang mewakili keseluruhan idenya. Tegasnya, satu - kata mewakili satu atau bahkan lebih frase atau kalimat. Oleh karena itu, frase ini disebut juga tahap holofrasis.

\section{Tahap dua - kata}

Fase ini berlangsung sewaktu anak berusia sekitar 18-24 bulan. Pada masa ini, kosakata dan gramatika anak berkembang dengan cepat. Anak-anak mulai menggunakan dua kata dalam berbicara. Tuturannya mulai bersifat telegrafik. Artinya, apa yang dituturkan anak hanyalah kata-kata yang penting saja, seperti kata benda, kata sifat, dan kata kerja. Kata-kata yang tidak penting, seperti halnya kalau kita menulis telegram, dihilangkan.

\section{Tahap banyak - kata}

Fase ini berlangsung ketika anak berusia 3-5 tahun atau bahkan sampai mulai bersekolah. Pada usia 3-4 tahun, tuturan anak mulai lebih panjang dan tata bahasanya lebih teratur. Dia tidak lagi menggunakan hanya dua kata, tetapi tiga kata atau lebih. Pada umur 5-6 tahun, bahasa anak telah menyerupai bahasa orang dewasa.

Pengetahuan mengenai pemerolehan bahasa dan tahapnya yang paling pertama didapat dari buku-buku harian yang disimpan oleh orang tua yang juga peneliti ilmu psikolinguistik. Dalam studi-studi 
yang lebih mutakhir, pengetahuan ini diperoleh melalui rekaman-rekaman dalam pita rekaman, rekaman video, dan eksperimen-eksperimen yang direncanakan. Tahap-tahap pemerolehan bahasa terdiri atas beberapa tahap, yaitu (a) tahap pengocehan (babbling); (b) tahap satu kata (holofrastis); (c) tahap dua kata; (d) tahap menyerupai telegram (telegraphic speech), (e) vokalisasi bunyi, (f) tahap satu kata atau holofrastis, (g) tahap dua kata, satu frase, dan (h) ujaran telegrafis (Tussolekha, 2015)

Menurut Soetjiningsih, anak-anak dilahirkan dengan mekanisme kemampuan untuk mengembangkan bicara dan keterampilan bahasa. Perkembangan bahasa adalah kemampuan anak untuk memberikan respon terhadap suara, mengikuti perintah dan berbicara sopan (Safitri, 2016).

Senada dengan pernyataan diatas, Fatmawati (2015), menyatakan bahwa terdapat tiga poin penting yang harus kita pahami terhadap mekanisme pemerolehan bahasa terhadap anak, yakni: Imitasi, dalam perolehan bahasa terjadi ketika anak menirukan pola bahasa maupun kosa kata dari orang-orang yang signifikan bagi mereka, biasanya orang tua atau pengasuh. Pengkondisian, mekanisme ini diajukan oleh B.F Skinner. Mekanisme pengkondisian atau pembiasaan terhadap ucapan yang didengar anak dan diasosiasikan dengan objek atau peristiwa yang terjadi. Oleh karena itu kosakata awal yang dimiliki oleh anak adalah kata benda. Kognisi sosial, anak memperoleh pemahaman terhadap kata (semantik) karena secara kognisi ia memahami tujuan seseorang memproduksi suatu fonem melalui mekanisme atensi bersama. Adapun produksi bahasa diperolehnya melalui mekanisme imitasi.
Bahasa pada anak-anak terkadang sulit kita artikan, karena anak pada umumnya masih menggunakan struktur bahasa yang masih kacau dan masih mengalami tahap transisi dalam berbicara, sehingga sulit untuk di pahami oleh mitra penuturrnya. Untuk menjadi mitra tutur pada anak dan untuk dapat memahami maksud dari pembicaran anak, mitra tutur harus menguasai kondisi atau lingkungan sekitarnya, maksudnya ketika anak kecil berbicara mereka menggukan media di sekitar mereka untuk menjelaskan maksud yang ingin di ungkapkan kepada mitra tuturnya di dalam berbicara. Selain menggunakan struktur bahasa yang masih kacau, anak-anak juga cenderung masih menguasai keterbatasan dalam kosa kata dan pelafalan fonemnya secara tepat (Sebayang, 2018)

Pada penelitian ini, peneliti fokus pada usia anak 14 bulan. Pada tahapan perkembangan bahasa anak, umur ini tergolong pada tahapan satu kata (12 bulan-18 bulan). Pada masa ini, anak sudah mulai belajar menggunakan satu kata yang memiliki arti yang mewakili keseluruhan idenya.Satu-kata mewakili satu atau bahkan lebih frase atau kalimat.Kata-kata pertama yang lazim diucapkan berhubungan dengan objekobjeknyata atau perbuatan.Kata-kata yang sering diucapkan orang tua sewaktu mengajak bayinya berbicara berpotensi lebih besar menjadi kata pertama yang diucapkan si bayi.

Memahami makna kata yang diucapkan anak pada masa ini tidaklah mudah. Untuk menafsirkan maksud tuturan anak harus diperhatikan aktivitas anak itu dan unsur-unsur non-linguistik lainnya seperti gerak isyarat, ekspresi,dan benda yang ditunjuk si anak. Menurut Tarigan (Tarigan, 2009) ada dua penyebab hal itu terjadi, yaitu sebagai berikut. 
Pertama, bahasa anak masih terbatas sehingga belum memungkinkan mengekspresikan ide atau perasaannya secara lengkap. Keterbatasan berbahasanya diganti dengan ekspresi muka, gerak tubuh, atau unsur-unsur nonverbal lainnya.

Kedua, apa yang diucapkan anak adalah sesuatu yang paling menarik perhatiannya saja. Sehingga, tanpa mengerti konteks ucapan anak, kita akan kesulitan untuk memahami maksud tuturannya.

Walaupun memahami makna kata yang diucapkan anak pada masa ini tidaklah mudah, tetapi komunikasi aktif dengan si anak sangat penting dilakukan. Penelitian semacam ini juga pernah pernah dilakukan oleh Hollysa Andini (Hollysa, 2018) dengan judul penelitian "Pemerolehan Bahasa Indonesia pada Anak Usia 0-2 Tahun: Kajian Psikolinguistik" data transkrip menunjukkan bahwa data pada usia 1-1,5 tahun sudah mulai mengucapkan kata-kata yang jelas. Produksi bunyi yamg muncul berupa katakata, seperti unda (Bunda), anyah (Ayah), dapur (dapur), kamar (Kaman). Tetapi, sesuai dengan kesimpulan penelitian ini perkembangan bahasa anak bisa berbedabeda pada setiap individunya, bisa berkembang cepat dan bisa juga lamban, tergantung pada tingkat atau jenjang usianya, kemampuan orang tuanya dan lingkungan yang aktif untuk mengembangkannya. Semakin tinggi usia seorang anak, semakin tinggi pula perkembangan kemampuan berbahasanya

Untuk dapat berbicara, anak perlu mengetahui perbendaharaan kata yang akan disimpan di otaknya dan ini bisa didapat ketika orang tua mengajak bicara. Selain itu, yang perlu diperhatikan dalam menghadapi anak yang memasuki usia ini adalah"jangan memakai bahasa bayi untuk anak-anak, melainkan dengan orang dewasa." Maksudnya, ucapkanlah dengan bahasa yang seharusnya di dengar sehingga si anak juga terpacu untuk berkomunikasi dengan baik.

\section{METODOLOGI}

Metode penelitian yang digunakan dalam penelitian ini adalah metode deskriptif dengan pendekatan kualitatif. Menurut Arikunto, metode deskriptif adalah metode yang menjelaskan data atau objek secara natural, objektif, dan faktual (apa adanya) (Tussolekha, 2015)

Metode deskriptif ini digunakan untuk menggambarkan hasil dari pengumpulan data yang telah dilakukan oleh peneliti, melalui metode simak dan rekam. Data yang diperoleh kemudian dikumpulkan dengan metode simak yang bertujuan untuk menyimak hasil ujaran anak secara baik. Setelah itu data lisan yang sudah diperoleh melalui hasil simakan dapat di bantu dengan teknik rekam yang bertujuan untuk merekam atau mengingat semua ujaran anak dalam penelitian bahasa yang sedang berlangsung dan observasi secara langsung tentang kemampuan bahasa anak.

Metode deskriptif dipilih oleh peneliti karena metode ini dapat memberikan gambaran secermat mungkin mengenai individu, keadaan, bahasa, gejala atau kelompok.

Menurut Margono (Margono, 2010) teknik pengumpulan data adalah cara yang dilakukan peneliti untuk mengumpulkan data yang objekif. Teknik pengumpulan data dalam penelitian ini dilakukan dengan cara: observasi dan dokumentasi. Dokumentasi ini berfungsi untuk menjadi bukti mengenai adanya proses pengamatan, dan melalui dokumentasi ini juga dapat menjadi suatu cara mengantisipasi adanya kekeliruan atau kesalahan dalam proses penilaian. Rekaman yang diambil secara 
tidak langsung dapat menjadi gambaran konkret mengenai bagaimana proses pengamatan terhadap anak

Penelitian ini dilakukan di rumah orang tua sang anak, yakni di Kecamatan Pasaman, dalam waktu yang berbeda. Sampel yang diambil hanya satu orang, anak laki-laki yang berusia 14 bulan yang bernama Riziq Alfath Afuero yang kebetulan anak dari kakak kandung penulis sendiri.

\section{HASIL DAN PEMBAHASAN}

Penulis mengamati seorang anak laki-laki yang bernama Riziq Alfath Aguero yang berusia 14 bulan. Penulis mengamati dari video-video rekaman yang telah penulis lakukan terhadap anak yang akan di amati. Pada pengamatan ini, penulis mengamati dua video. Berikut penjelasan pada dua tersebut.

Pada video pertama, video tersebut direkam pada saat Riziq baru memasuki umur 1 tahun atau 12 bulan. Pada video tersebut Riziq sedang latihan berjalan menuju ibunya tanpa bantuan dari siapapun, keadaan tersebut memaksanya harus mampu melangkahkan kakinya sendiri, tanpa ada pegangan. Dengan keadaan seperti itu, sang anak terlihat ketakutan, susah menyeimbangkan badannya, lalu dia merengek sambil berkata "tatatatata" sambil memekikkan suaranya menunjukkan bahwa dia takut, dan membutuhkan uluran tangan ibunya untuk berjalan menuju ibunya.

Pada video kedua, Riziq sudah memasuki usia 14 bulan. Pada video tersebut, dia sedang makan disuapi ibunya, dan ayahnya yang berada di dekatnya juga sedang makan dan memegang piring makannya tersebut. Pada saat ibunya menyuapi sang anak, anak malah menutupi mulutnya dan menggelengkan kepalanya. Hal ini menandakan bahwa sang anak tidak mau makan, entah itu ia sedang tidak lapar atau makanannya tidak enak. Tapi yang paling jelas, dengan gerakan seperti itu menandakan bahwa ia menolak untuk makan. Pada tingkahnya yang lain, sang anak menunjuk-nunjuk piring sang ayah sambil berkata "ba...bah...tuh" walaupun bunyi-bunyi bahasa yang dihasilkan anak belumlah bermakna, bunyi itu berupa vokal atau konsonan tertentu tetapi tidak mengacu pada kata atau makna tertentu, tapi sang ayah mencoba memahami apa yang diinginkan sang anak. Sang ayah memberikan kerupuk yang ditunjuk-tunjuk sang anak tadi dan sang anak menerima kerupuk tersebut. Ternyata sang anak menginginkan kerupuk yang ada pada piring tersebut. Pada usia ini Riziq, motoriknya berkembang dengan cepat, misalnya gerakan tangannya untuk meminta sesuatu, atau gelengan terhadap sesuatu yang tidak ia suka.

Berdasarkan pengamatan dari peneliti, pada saat Riziq memasuki usia 15 bulan, Rizi sudah mampu mengucapkan kata "ba" yang berarti "ibu", "yah" yang berarti "ayah", dan "mak" yang berarti "mamak" (Paman).

Hal yang diamati peneliti sesuai dengan pendapat Tarigan (Kdk. Ary Kunti Putri, I Wayan Rasna1, 2012) , untuk memahami makna kata yang diucapkan anak pada masa ini tidaklah mudah. Untuk menafsirkan maksud tuturan anak harus diperhatikan aktivitas anak itu dan unsurunsur non-linguistik lainnya seperti gerak isyarat, ekspresi,dan benda yang ditunjuk si anak. Ada dua penyebab, yaitu:

Pertama, bahasa anak masih terbatas sehingga belum memungkinkan mengekspresikan ide atau perasaannya secara lengkap. Keterbatasan berbahasanya diganti dengan ekspresi muka, gerak tubuh, atau unsur-unsur nonverbal lainnya. 
Kedua, apa yang diucapkan anak adalah sesuatu yang paling menarik perhatiannya saja. Sehingga, tanpa mengerti konteks ucapan anak, kita akan kesulitan untuk memahami maksud tuturannya.

Penyebab pertama di atas, sesuai dengan dua video yang telah diamati oleh pengamat. Bahwasanya bahasa anak masih terbatas. Maka dengan ekspresi muka dan gerak tubuh yang membantu orang sekitar untuk memahami yang dimaksudnya. Misalnya pada video pertama yang memperlihatkan ekspresi ketakutan. Pada video yang kedua, anak menunjuk-nunjuk apa yang ia inginkan tapi tidak mampu untuk mengucapkannya.

Sama halnya dengan penelitian tentang pemerolehan bahasa anak yang dilakukan oleh Hollysa Andini (Hollysa, 2018) yang mengungkapkan bahwa pemerolehan morfologi untuk anak usia 02 tahun setelah dilakukan transkripsi atas data hasil penelitian didapatkan fakta bahwa untuk anak usia 0-1 tahun tidak dapat diuraikan, karena bunyi bahasa yang diucapkannya masih belum dapat diidentifikasikan. Hal ini menuntut kita lebih peka tentang kemauan atau keinginan sang anak dengan gerak-gerik dan aktivitasnya sehari-hari.

Berdasarkan pengamatan yang telah dilakukan penulis terhadap subjek, perkembangan bahasa subjek termasuk golongan lambat, karena jika dibandingkan dengan perkembangan anak-anak lainnya, pada saat umur 12-14 mereka sudah mampu mengucapkan kata yang mulai jelas, seperti penelitian yang dilakukan oleh Budhiono (Budhiono, 2011), hasil penelitiannya menunjukkan bahwa subjek yang ia teliti pada saat usia 11 bulan, subjek sudah mulai mahir dan terampil berbahasa. Kata yang bisa ia katakan seperti mama, dedek (adik), eyan (eyang).
Anak-anak yang bicaranya tidak jelas atau sulit ditangkap dalam istilah psikologi/psikiatri disebut mengalami gangguan artikulasi atau fonologis. Namun, gangguan ini wajar terjadi karena tergolong gangguan perkembangan. Dengan bertambahnya usia, diharapkan gangguan ini bisa diatasi. Kendati begitu, gangguan ada yang ringan dan berat.

Golongan ringan misalnya, saat usia 3 tahun anak belum bisa menyebut [1,], [r], dan [s]. sehingga kata mobil disebut "mobing" atau lari dibilang "lali". Biasanya gangguan ini akan hilang dengan bertambah usia anak atau bila kita melatihnya dengan membiasakan menggunakan bahasa yang baik dan benar. Hanya saja untuk anak yang tergolong "pemberontak" atau negativistiknya kuat, umumnya enggan dikoreksi. Sebaiknya kita tidak memaksa meski tetap memberi tahu yang benar dengan mengulang kata yang dia ucapkan. Misal, "Ma, yuk, kita lali-lali", segera timpali, "Oh, maksud Adek, lari-lari” (Rina Devianty, 2016).

\section{KESIMPULAN}

Perkembangan bahasa pada anak usia dini sangat penting karena dengan bahasa sebagai dasar kemampuan seorang anak akan dapat meningkatkan kemampuankemampuan yang lain. Kemampuan berbahasa anak tidak diperoleh secara tibatiba atau sekaligus, tetapi bertahap.

\section{UCAPAN TERIMA KASIH}

Peneliti mengucapkan terimakasih kepada kedua orang tua (Amril. $\mathrm{R}$ dan Guslinar, S. Pd) dan kedua pembimbing (Prof. Dr. Syahrul R, M. Pd. dan Dr. Erizal Gani, M. Pd.) telah memberikan semangat dan dukungan kepada penulis sampai penelitian ini selesai. Ucapan terima kasih juga disampaikan kepada tim editor Jurnal Obsesi yang telah memberikan saran, 
152 Memahami Bahasa Anak Usia 14 Bulan melalui Unsur "Non-Linguistik"

kritik, dan rekomendasi untuk perbaikan artikel ini.

\section{DAFTAR PUSTAKA}

Budhiono, R. H. (2011). Pemerolehan fonologis pada anak usia $0-2$ tahun. Adabyyat, 10(1).

Fatmawati, S. R. (2015). Pemerolehan bahasa pertama anak menurut tinjauan psikolinguistik. Lentera, 18(1), 6375.

Hollysa, A. (2018). pemerolehan bahasa Indonesia pada anak usia 0-2 tahun: Kajian Psikolinguistik. LINGUA, 15(1), 45-52. https://doi.org/DOI: 10.30957

Kdk. Ary Kunti Putri, I Wayan Rasna1, I. N. S. (2012). pemerolehan bahasa Indonesia pada anak usia dini di desa Beraban, kecamatan Kediri kabupaten Tabanan. Program Studi Pendidikan Bahasa, Program Pascasarjana Universitas Pendidikan Ganesha Singaraja, Indonesia. Retrieved from http://oldpasca.undiksha.ac.id/e journal/index.php/jurnal_bahasa/articl e/view/1436/1109

Margono, S. (2010). Metodologi Penelitian Pendidikan. Jakarta: Rineka Cipta.

Rina Devianty. (2016). Pemerolehan bahasa dan gangguan bahasa pada anak usia batita. Raudhah, 4(1).

Safitri, Y. (2016). Faktor-faktor yang berhubungan dengan perkembangan bahasa balita di UPTD kesehatan baserah tahun 2016. Jurnal Obsesi, I(2), 148-155.

Sebayang, S. K. H. (2018). Analisis pemerolehan bahasa pertama (bahasa melayu ) pada anak usia 3 tahun. Jurnal Pena Indonesia, 4(1), 106114.

Tarigan, H. G. (2009). Psikolinguistik. Bandung: Angkasa.

Tussolekha, R. (2015). Mekanisme pemerolehan bahasa pada anak usia satu dan lima tahun. Jurnal Pesona,
1(2), 59-70.

Urška Fekonja, L. M. U. \& S. K. (2014). Free play as a context for children's language development. University of Ljubljana, Faculty of Arts, Slovenia. Retrieved from https://www.researchgate.net/publicat ion/267772762

Winda Rianti. (2016). Meningkatkan kemampuan mengenal lambang bilangan melalui permainan tata angka pada anak usia dini. Jurnal PAUD Tambusai, 2(2), 36-42. 